\title{
CHARACTERIZATION OF SOUR (PRUNUS CERASUS L.) AND SWEET CHERRY (PRUNUS AVIUM L.) VARIETIES WITH FIVE ISOZYME SYSTEMS ${ }^{1}$
}

\author{
REMEDIOS MORALES CORTS ${ }^{2}$, LUCIANOCORDEIRO RODRIGUES ${ }^{3}$, \\ JESÚS MARIA ORTÍZ MARCIDE ${ }^{4}$, RODRIGO PÉREZ SÁNCHES ${ }^{5}$
}

\begin{abstract}
Extracts from young leaves of nine sweet cherry (Prunus avium L.) and eight sour cherry (Prunus cerasus L.) varieties, located in the germplasm collection of the 'Direção Regional de Agricultura da Beira Interior' (Fundão, Portugal), were analysed for five isozyme systems in order to characterise these varieties and detect problems of synonymies and homonymies that frequently present. The sweet and sour cherry varieties analyzed showed low isoenzymatic polymorphism, being PGM and PGI the systems with the highest discrimination power. These systems presented seven and five different zymogrames, respectively. IDH showed four patterns. SKDH and 6-PGD grouped the varieties only into two patterns. The evident and discriminant restrictions of this type of analysis had got results that have only been a complement for agronomical and morphological characterization.
\end{abstract}

Index terms: dendrogram; polymorphism; starch gel electrophoresis; zymogram.

\section{CARACTERIZAÇÃO DE VARIEDADES DE GINJEIRA (PRUNUS CERASUS L.) E CEREJEIRA (PRUNUS AVIUM L.) EM CINCO SISTEMAS ISOENZIMÁTICOS}

RESUMO - Nove extratos de folhas com desenvolvimento encompleto foram obtidos de 9 variedades de cerejeira (Prunus avium L.) e 8 de ginjeira (Prunus cerasus L.), localizados no campo de germoplasma da "Direcção Regional de Agricultura da Beira Interior" (Fundão, Portugal). Esses extratos foram analisados para 5 sistemas isoenzimáticos a fim de caracterizar essas variedades e simultaneamente detectar sinonímias e homonímias, freqüentes neste tipo de estudos. As variedades de cerejeira e ginjeira analisadas mostraram baixo polimorfismo isoenzimático, sendo que os sistemas PGM e PGI mostraram maior poder de discriminação. Estes sistemas apresentaram 7 e 5 zimogramas diferentes, respectivamente. IDH mostrou 4 padrões. SKDH e 6-PGD agruparam as variedades em 2 padrões. Os evidentes limites discriminatórios desse tipo de análise serviram somente de complemento para a caracterização agronômica e morfológica.

Termos para indexação: dendrograma; polimorfismo; gel de electroforese de amido; zimograma.

\section{INTRODUCTION}

Sweet cherry (Prunus avium L., Rosaceae, $2 \mathrm{n}=16$ ) is a deciduous, allogamous and generally self-incompatible species. It is cultivated for its edible fruits and for the wood. Sour cherry (Prunus cerasus L., Rosaceae, $2 \mathrm{n}=32$ ) is cultivated for its sharp and succulent fruits, that are mostly destined to produce jam, jelly, stewed fruit, marmalade and syrup in food industry. Also sour cherry is cultivated as sweet cherry rootstock. Both species were originated around the Black and Caspian seas and these species were cultivated in temperate and cool regions. Both sweet and sour cherries were stretching slowly from the origin to others regions by the human and animal migrations (Moreno \& Manzano, 2002). The world productions of these two species by 2005 added up to 1.86 and 1.23 millions of metric tons, respectively (Faostat, 2007). In the Iberian Peninsula the production of sweet and sour cherries reaches about 93,900 t per year.

Within the area of Fundão (Portugal), that is the main production area of sour and sweet cherries, a collection of varieties was established in 1991, with the aim of preserve the autochthonous varieties that are in regression due to the introduction of new varieties mainly from United States, France and Canada. The maintenance of this plant material is important to avoid the genetic diversity loss and for their use in future breeding works.

Isozyme markers have been successful used in identification and characterization of cultivars, natural populations and accessions in germplasm collections (Fernandez de Souza \& Primo, 2001). In fruits species isozyme studies have been carried out for identification of rootstocks and varieties, being able to detect and solve problems of synonymies (two or more names used for the same variety) and homonymies (different varieties are denominated with the same name) that frequently occur (Friend \& Carter, 1989; Mowrey \& Werner, 1990; Huang \& Layne, 1997).

Isozymes have several important advantages in comparison to the more traditional morphological characterization, since they allow the identification of plants in early stages of development, save time and space, and are not affected by the environmental conditions (Torres, 1990). Moreover, it is simple, economic, fast and reproducible technique, whose results can be observed in a short time by using young plants. In modern

'(Trabalho 089-07). Recibido el 02-04-2007. Aceptado para publicación el 04-14-12-2007.

2Dra.Ingeniero Agrónomo.Facultad de Ciencias Agrarias, Universidad de Salamanca. Filiberto Villalobos 119. 37007 Salamanca (Spain). E-mails: reme@usal.es.

${ }^{3}$ Dr.Ingeniero Agrónomo. Escola Superior Agrária. Apartado 1172. 5301-855 Bragança (Portugal). E-mail: lucoro@ipb.pt.

${ }^{4}$ Dr.Ingeniero Agrónomo. Dpto. Biología Vegetal. Universidad Politécnica de Madrid. 28040 Madrid (Spain). E-mail: jesusmaria.ortizm@upm.es.

${ }^{5}$ Licenciado en Ciencias Ambientales e Ingeniero Técnico Agrícola.rodrigopere@usal.es. 
fruticulture, optimised and rapid methods are needed for plant material identification.

Recently, Daell (2004) analysed some isozyme markers to characterize the genetic relationships among 43 stone fruits accessions from the genus Prunus including Prunus avium L. species. Some authors that have also carried out different studies of Prunus avium characterization based on isozymes are Arulsekar \& Parfitt, (1986), Boskovic et al., (1997) and Pashkoulov et al., (2000). By the use of 10 isozyme systems, Granger et al. (1993) identified 76 sweet cherry varieties and found that some of them with the same morphological characters, which were previously considered as the same variety, could be separated based on the differences on the isozyme results. Beaver et al. (1995) studied the isozyme systems: isocitrate dehydrogenase (IDH), phosphoglucoisomerase (PGI), phosphoglucomutase (PGM), shikimate dehydrogenase (SKDH), 6-phosphogluconate dehydrogenase (6-PGD), leucine aminopeptidase (LAP) and malate dehydrogenase (MDH) in a total of 36 sweet, sour and ground cherries, verifying that this technique was efficient in detect polymorphism among them. Santi \& Lemoine (1990a, 1990b) and Frascaria et al. (1993) have carried out important studies for identification of $P$. cerasus and $P$. avium. At the present day, although DNA techniques are much utilised, the use of isozymes as markers can be comparable to many of those techniques and even provide more consistent results (Vázquez et al., 2000).

The objective of the present work is the identification and characterisation by isozyme analysis of 9 sweet cherry and 8 sour cherry varieties located at the germplasm collection of Fundão (Portugal). Detection of the apparently existing synonymies and homonymies of this collection is intended.

\section{MATERIAL AND METHODS}

\section{Plant material}

The trees used for the study were located in Fundão (Portugal) in the germplasm collection of sweet and sour cherries of the 'Direcção Regional de Agricultura da Beira Interior'. The plantation was established in 1991. Sweet cherry studied varieties were: 'Lisboeta', 'Francesa de Alenquer' and 'Morangão' that seem to have been originally French varieties, adapted to Portugal; 'Maringa', initially thought to be Portuguese, although it could have an Italian origin; 'Saco 1' from Montalegre (Portugal) and 'Saco 2' that is the authentic 'De Saco' from Cova da Beira (Portugal), grown by farmers of the region. Sour cherry studied varieties were: 'Sobral, Martinho and Pedro Miguel' 'D'Óbidos', as well as 'Seixas', from Alcobaça (Portugal); 'Galega', 'Garrafal Rosa', 'Garrafal' and 'Garrafal Negra', from a private nursery. Moreover, three varieties of sweet cherry were included as reference varieties: early 'Precoce Bernard', midseason 'Burlat' and late 'Tardif de Vignole'. 'Garrafal' was the reference for sour cherries.

Methods

The isozymes were extracted from spring shoots, with two repetitions for each variety. The sampled young leaves were kept between 0 and $4^{\circ} \mathrm{C}$ from harvest until the analyses. Each sample consisted of $0.5 \mathrm{~g}$ of leaves that were placed in a mortar and crushed with $12 \mathrm{ml}$ extraction buffer prepared according to Arulsekar \& Parfitt (1986). The extract was transferred to eppendorf tubes for centrifugation $\left(3000 \mathrm{rpm}, 4^{\circ} \mathrm{C}\right.$ during 5 minutes). Whatman paper $\left(\mathrm{n}^{\circ} 3\right)$ of $0.5 \times 10 \mathrm{~mm}$ was imbibed with the supernatant from each sample and placed into the gel.

Electrophoresis was carried out for three hours at $200 \mathrm{~V}$ in $11 \%$ starch gels. They were prepared with $\mathrm{pH} 7.0$ histidine buffer. Electrode buffer was $\mathrm{pH} 7.0$ Tris-citrate, according to the protocols of Torres (1990). The process was done at $4^{\circ} \mathrm{C}$.

Five isozyme systems were analysed: isocitrate dehydrogenase (IDH), phosphoglucoisomerase (PGI), shikimate dehydrogenase (SKDH), 6-phosphogluconate dehydrogenase (6-PGD) and phosphoglucomutase (PGM).

Staining was accomplished as follows: 1) IDH: $12 \mathrm{ml} \mathrm{pH}$ 8.0 Tris- $\mathrm{HCl} 1 \mathrm{M}$ plus $2 \mathrm{ml} 10 \% \mathrm{MgCl}_{2}$ were prepared and added to $86 \mathrm{ml}$ distilled water. The reagents used were: $100 \mathrm{mg}$ isocitric acid, $15 \mathrm{mg}$ NADP (Nicotinamide Adenine Dinucleotide Phosphate), 20 mg MTT (3-4,5-dimethyl thiazolyl-2,5-diphenyl tetrazolium bromide) and $5 \mathrm{mg}$ PMS (Phenazine methosulphate). 2) PGI: $12 \mathrm{ml} \mathrm{pH} 8.0$ Tris- $\mathrm{HCl} 1 \mathrm{M}, 2 \mathrm{ml} 10 \% \mathrm{MgCl}_{2}, 2 \mathrm{ml}$ fructose 6-P-Na ${ }_{2} 0.036 \mathrm{M}, 1 \mathrm{ml} 0.5 \%$ glucose 1-6-diphosphate and 40 units of glucose 6-P dehydrogenase solved in $4 \mathrm{ml}$ distilled water, were added to $79 \mathrm{ml}$ distilled water. 3) SKDH: $10 \mathrm{ml} \mathrm{pH} 8.0$ Tris$\mathrm{HCl}$ 1M, $50 \mathrm{mg}$ shikimic acid, $15 \mathrm{mg}$ MTT, $10 \mathrm{mg}$ NADP, $5 \mathrm{mg}$ PMS plus $90 \mathrm{ml}$ distilled water. 4) 6-PGD: $5 \mathrm{ml} \mathrm{pH} \mathrm{8.0} \mathrm{Tris-HCl} \mathrm{1M,}$ $50 \mathrm{mg}$ 6-phosphogluconic acid, $15 \mathrm{mg}$ MTT, $10 \mathrm{mg}$ NADP, $5 \mathrm{mg}$ PMS plus $95 \mathrm{ml}$ distilled water. 5) PGM: $12 \mathrm{ml} \mathrm{pH} 8.0$ Tris- $\mathrm{HCl} 1 \mathrm{M}$, $2 \mathrm{ml} \mathrm{10 \%} \mathrm{MgCl}_{2}, 5 \mathrm{ml} 1 \%$ glucose 1-P Na, $1 \mathrm{ml} 0.05 \%$ glucose 16 diphosphate and 40 units of glucose 6-P dehydrogenase solved in $4 \mathrm{ml}$ distilled water, were added to $76 \mathrm{ml}$ distilled water.

The gels were incubated in the dark at $37^{\circ} \mathrm{C}$ for $30 \mathrm{~min}$ (Arulsekar \& Parfitt, 1986). At the end of the staining process the gels were visually observed and the bands of the phenotypes were interpreted by means of NTSYS program (Numerical Taxonomy System). Using UPGMA method (Unweighted Pair Group Method with Arithmetic Mean) a dendrogram of genetic relation between varieties was obtained.

\section{RESULTS AND DISCUSSION}

The different types of zymograms are represented in Fig. 1. The patterns for each one of the studied varieties are displayed in Table 1.

The IDH showed four different zymograms; two of them, $\mathrm{A}$ and $\mathrm{B}$, in sweet cherries and three, A, C and D in sour cherries. Santi \& Lemoine (1990a, 1990b) also obtained three different phenotypes for the IDH in sour cherries; Beaver et al. (1995) indicated that sour cherries, tetraploid, have more polymorphism than sweet cherries that are diploid. Our results also agree with them for this enzyme.

PGI presented five patterns of zymograms. The studies carried out by Granger et al. (1993) indicate that this isozyme system has a polymorphism that makes it adequate as molecular marker for fruit trees. This system is consequently broadly used 
for plant characterization, mainly in germplasm banks (Beaver \& Crawford, 1986; Gottlieb, 1981 and 1982; Weeden \& Gottlieb, 1979 and 1980). In this study five patterns were obtained (Fig. 1), two of them, A and B, for sweet cherries and four, B, C, D and E, for sour cherries. Similarly to the IDH system, this one has also more polymorphism for sour cherries, which agrees to Beaver et al. (1995).

The system SKDH showed a low polymorphism. Only two patterns were obtained, A and B for sweet cherries and only A for sour cherries. It is the only case where sour cherries presented the same pattern and had less polymorphism than sweet cherries. However, Granger et al. (1993), working with sweet cherry extracts, stated that this system had enough polymorphism to be able to distinguish among some varieties.

PGM showed seven patterns (Fig.1), being the system with the highest discrimination power. Beaver et al. (1995) also considered that this system had a high polymorphism and was useful for characterization of sweet and sour cherry varieties.

The 6-PGD system displayed only one pattern for sweet cherries and two for sour cherries, distinguishing in this case the three varieties from ' $D$ 'Obidos' from the others.

In general, a low polymorphism has been found in this study, comparative with studies of Santi \& Lemoine (1990a, 1990b), Granger et al. (1993) and Frascaria et al. (1993). It can be explained why some varieties used in the present work have a closed genetic base.

The five isozyme systems together are able to distinguish among the sweet cherry varieties except 'Burlat', 'Precoce Bernard' and 'Tardif de Vignole' that have the same patterns. These three varieties were obtained in France (Gella et al., 2001). In a recent study Cordeiro (2004) observed that these three varieties, although having similarities in the morphology of flowers, leaves and fruits, could be distinguished by some parameters such as fruit sphericity and stalk length. Marked differences in the phenology as well as in the morphological characteristics of the trees were also detected (Gella et al., 2001). Thus, the isozymes studies showed some limits to varieties identification and it is necessary to combine these studies with morphological and agronomical characterization in order to obtain better results (Altube et al., 2001).

In sour cherries, the three varieties 'D'Obidos' presented the same isozyme patterns. Morphological and phenological characteristics did not show differences (Cordeiro, 2004). These results indicated that they should be considered as synonymies of the same variety. Also the two varieties 'Galega' and 'Garrafal Rosa' have the same isozyme patterns; morphological and phenological characteristics are also very similar (Cordeiro, 2004) and could be considered as synonymies of the same variety.

The dendrogram obtained from the isozyme results (Fig. 2 ), at a similarity level of 0.57 , showed a group that includes all the sweet cherry varieties while the sour cherries are not grouped except in the cases of the proposed synonymies. Dendrogram showed clear separation between sweet cherries and sour cherries varieties.

The two sweet cherry varieties 'Saco 1' and 'Saco 2' were included in the germplasm collection under the same name, 'Saco'.
Morphological characterization (Cordeiro, 2004) showed only slight differences between them; isoenzymatic analysis presents different patterns in four isozyme systems (Table 1). The obtained dendrogram (Fig. 2) showed that 'Saco 1' was the most distant variety among sweet cherries. These two varieties should be considered as a case of homonymy. The varieties 'Saco 2' and 'Morangao' have as origin centre the area of Cova da Beira (Portugal), while 'Saco 1' was originated in Montealegre (Portugal) (T. Ferreira, personal communication).

The three French varieties ('Burlat', 'Precoce Bernard' and 'Tardif de Vignole') are grouped at a similarity of 0.87 in the dendrogram (Fig. 2) with 'Lisboeta', 'Maringa' and 'Francesa de Alenquer'; one possible explanation of this similarity is that the last three varieties were originated in France and taken into Portugal several decades ago.

For sour cherries, except when identical patterns were obtained, the variability was higher than the sweet cherries. A reason for this higher variability could be the sour cherry tetraploidy. Only the two varieties 'Garrafal' and 'Garrafal Negra' have some similarity of 0.49 (Fig. 2). Seixas and the three 'D'Obidos' varieties appeared highly separated in the dendrogram. The three 'D'Obidos' varieties showed more drooping tree habit and shorter leaves than the others sour cherry varieties (Cordeiro, 2004). Dendrogram permitted clearly separation between sweet cherry and sour cherry species and indicated the genetic diversity among varieties. Furthermore, the possibility of studying the genetic diversity among different cultivars will benefit cherry breeding programmes by helping to take decisions on parental genotypes for crosses, and germplasm management to maximise the conserved diversity. This is becoming increasingly important to conserve the existing variability in the wild stands of these species scattered through most European and some Asian countries, especially due to the progressive narrowing of the genetic base (Wünch \& Hormaza, 2002).

TABLE 1 - Model of patterns in five isozyme systems in sweet (sw) cherry and sour (so) cherry varieties.

\begin{tabular}{llllll}
\hline Variedad & IDH & PGI & SKDH & PGM & 6-PGD \\
\hline 'P. Bernard'(sw) & A & A & A & A & A \\
'Burlat'(sw) & A & A & A & A & A \\
'T. de Vignole'(sw) & A & A & A & A & A \\
'Fr. de Alenquer'(sw) & A & A & A & B & A \\
'Lisboeta'(sw) & A & A & A & C & A \\
'Maringa'(sw) & B & A & A & A & A \\
'Morangao'(sw) & B & B & A & C & A \\
'Saco 1'(sw) & A & A & B & A & A \\
'Saco 2'(sw) & B & B & A & D & A \\
'Galega'(so) & A & C & A & E & A \\
'Garrafal Rosa'(so) & A & C & A & E & A \\
'Garrafal Negra'(so) & C & B & A & F & A \\
'Garrafal'(so) & D & D & A & F & A \\
'Seixas'(so) & D & C & A & A & A \\
'M. D'Obidos'(so) & A & E & A & G & B \\
'P.M. D'Obidos'(so) & A & E & A & G & B \\
'S. D'Obidos'(so) & A & E & A & G & B \\
\hline
\end{tabular}




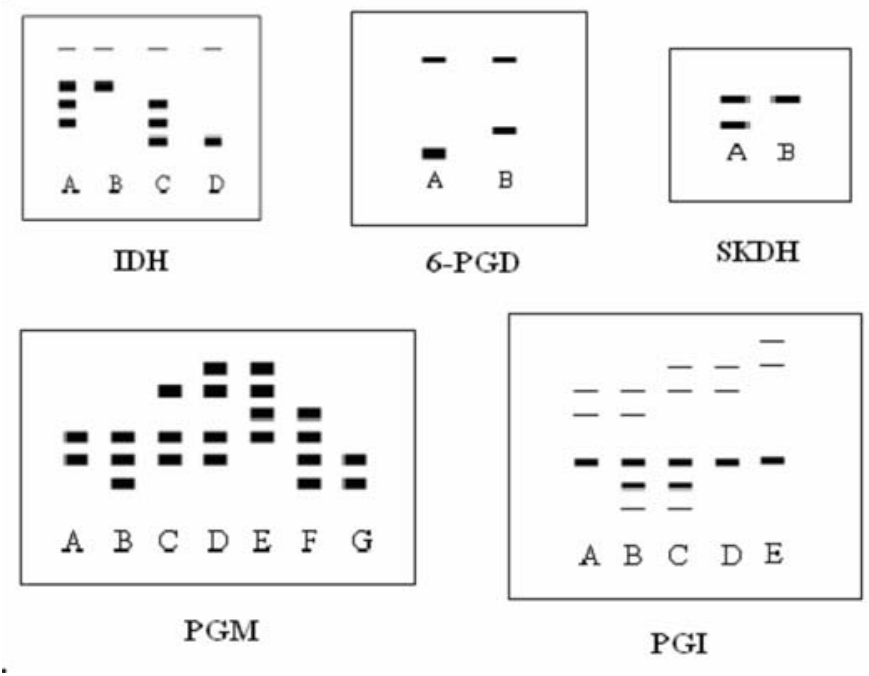

FIGURE 1 - Zimogrames obtained for five isoenzimatic systems in sweet cherry and sour cherry varieties.

\section{CONCLUSION}

The main conclusion of this study is that the sweet and sour cherry varieties analysed showed low isoenzymatic polymorphism, being PGM and PGI the systems with the highest discrimination power. These systems presented seven and five different zymogrames, respectively. Thus, the use of the isozyme analysis for characterization of sweet and sour cherries is recommended but it must be combined with the agronomical and morphological characterization in order to assess or reject identities among varieties. Some times different varieties can present the same zymogrames. The results, together with Cordeiro (2004) works indicated that the three varieties 'Sobral, Martinho and Pedro Miguel D 'Óbidos' should be considered as synonymies of the same variety. Also 'Galega' and 'Garrafal Rosa' could be considered as synonymies. 'Saco 1' and 'Saco 2' should be considered as a case of homonymy.

\section{REFERENCES}

ALTUBE, H.A.; ONTIVERO, M.; RIVATA, R.S.; TABORDA, R.J. Utilización de isoenzimas de extractos de hojas en la caracterización de cultivares de duraznero (Prunus persica (L) Batsch). Revista Brasileira de Fruticultura, Jaboticabal, v. 23, n. 2, p. 345-349, 2001.

ARULSEKAR, S.; PARFITT, D.E. Isozyme analysis procedures for stone fruits, almond, grape, walnut, pistachio and fig. HortScience, Alexandria, v. 21, n. 4, p. 928-933, 1986.

BEAVER, J.A.; IEZZONI, A.F.; RAMM, C.W. Isozyme diversity in sour, sweet and ground cherry. Theoretical and Applied Genetics, New York, v. 90, n. 6, p. 847-852, 1995.

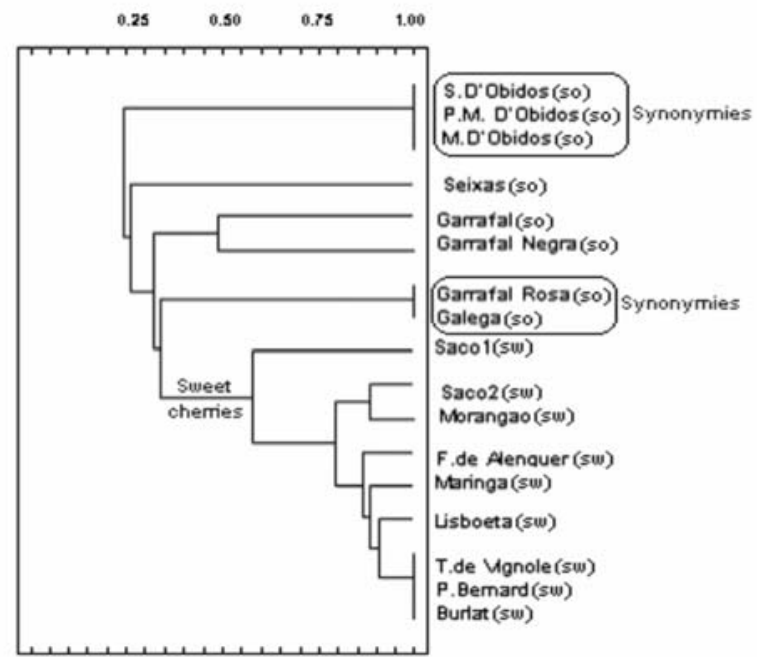

FIGURE 2- Dendrogram of relation between varieties (UPGMA method)by using isozyme studies in sweet (sw) cherry and sour (so) cherry varieties.

BEAVER, R., J.; CRAWFORD, J. Allozyme divergence among five diploid species of Antenaria (Asteracea inulae) and their diploid derivatives. American Journal of Botany, Columbus, v. 73, p. 287-296, 1986.

BOSKOVIC, R.; TOBUTT, K.R.; NICOLL, F.J. Inheritance of isoenzymes and their linkage relationships in two interspecific cherry progenies. Euphytica, Netherlands, v. 93, p. 129-143, 1997.

CORDEIRO, L. Caracterização morfológica e morfométrica de variedades portuguesas de cerejeira e ginjeira. Alcobaça: Centro Operativo e Tecnológico Hortofrutícola Nacional, 2004. 67 p. Boletím Técnico

DAELL, K. Genetic characterization using isozyme analysis in the genus Prunus. Korean Journal of Horticultural Science \& Technology, Suwon, v. 22, n. 3, p. 321-327, 2004.

FAOSTAT - FOOD AND AGRICULTURE ORGANIZATION STATISTICS. Available in: <http://apps.fao.org/page/ collections?subset=agriculture $>$. Access at: 6 march 2007 .

FERNANDEZ DE SOUZA, R.; PRIMO BETIOLI, E. Análalise da varriabilidade de isoenzimas em acessos e cultivares de girasol. Pesquisa Agropecuária Brasileira, Brasília, v.36, n 5, p. 771779, 2001.

FRASCARIA, N.; SANTI, F.; GOUYON, P.H. Genetic differentiation within and among population of chestnut (Castanea sativa Mill.) and wild cherry (Prunus avium L.). Heredity, London, v. 70, p. 634-641, 1993. 
FRIEND, H.A.; CARTER, G.E. Isozyme analysis for the identification of Prunus species and F1 hybrids. Acta Horticulturae, Wageningen, v. 254, p. 243-248, 1989.

GELLA, R.; FUSTERO, R.; RODRIGO, J. Variedades de cerezo. Zaragoza: Diputación de Aragón Publishers, 2001. 118 p. CDROM

GOTTLIEB, L.D. Electrophoretic evidence and plant populations. Progress in Phytochemistry, Tarrythown, v.7, p. 1-46, 1981.

GOTTLIEB, L.D. Conservation and duplication of isozymes in plants. Science, Washington, v.216, p. 373-379, 1982.

GRANGER, A.R.; CLARK, G.R.; JACKSON, J.F. Sweet cherry cultivar identification by leaf isozyme polymorphism. Theoretical Applied Genetics, New York, v. 86, n. 4, p. 458-464, 1993.

HUANG, H.; LAYNE, D.R. Using isozyme polymorphism for identifying and assessing genetic variation in cultivated pawpaw (Asimia triloba (L.) Dunal). American Society for Horticultural Science Journal, Alexandria, v. 122, n. 4, p. 504-511, 1997.

MORENO, J.; MANZANO, M.A. Variedades de cerezo para el Valle del Jerte. Badajoz: Junta de Extremadura Publishers, 2002. $78 \mathrm{p}$.

MOWREY, B.D.; WERNER, D.J. Development specific isozyme expression in peach. HortScience, Alexandria, v. 25, n. 2, p. 219$222,1990$.

PASHKOULOV, D.T.; TOBUTT, K.R.; BOSKOVIC, R. Comparison of isoenzymes in Prunus avium separated by two different electrophoretic techniques. Plant Breeding, Oxford, v. 119, n. 2, p. $153-156,2000$.
SANTI, F.; LEMOINE, M. Genetic markers for Prunus avium L. 1. Inheritance and linkage of isozyme loci. Annales des Sciences Forestieres, France, v. 47, n. 1, p. 131-140, 1990a.

SANTI, F.; LEMOINE, M. Genetic markers for Prunus avium L.: Inheritance and linkage of isozyme loci. Annales des Sciences Forestieres, France, v. 47, n. 2, p. 131-139, 1990b.

TORRES, A.M. Isozyme analysis of tree fruits. In: SOLTIS, D.E., SOLTIS, P.S. (Eds.). Isozymes in plant biology. London: Chapman and Hall, 1990. cap. 9, p. 192-205.

VÁZQUEZ, J.F.; SÁNCHEZ-YÉLAMO, M.; CARRILLO, J.M. Marcadores morfológicos y bioquímicos. In: NUEZ, F., CARILLO, J.M. (Eds.). Los marcadores genéticos en la mejora vegetal. Valencia: Servicio de Publicaciones de la Universidad de Valencia, 2000. cap. 2, p. 23-90.

WEEDEN, N.F.; GOTTLIEB, L.D. Distinguishing allozymes and isozymes of phosphoglucoisomerase by electrophoretic comparisons of polen and somatic tissues. Biochemiscal Genetics, New York, v. 17, p. 287-296, 1979.

WEEDEN, N.F.; GOTTLIEB, L.D. The identification and isolation of cytoplasmic enzymes from pollen. Plant Physiology, Rockville, v. 66, p. $400-403,1980$.

WÜNSH, A; HORMAZA, J.I. Molecular characterisation of sweet cherry (Prunus avium L.) genotypes using peach (Prunus persica (L.) Bastsch) SSR sequences. Heredity, London. v. 89, p. 56-63, 2002. 